doi:10.18575/msrs.sm.e.17.03 UDC 616.34-007.43-089.5:616-007.43 COBISS.RS-ID 6396696

\title{
Complications During Surgical Treatment of Incarcerated Inguinal Hernia
}

\begin{abstract}
Introduction: An incarceration of inguinal hernia is a life-threatening condition and represents the most frequent complication, particularly in the elderly patients. It may compromise vascularisation of the contents of the hernia. A surgical treatment of the incarcerated inguinal hernia represents one of the most frequent surgical interventions in elderly patients and it grows proportionally with the age.
\end{abstract}

Aim of the Study: The aim of the study is to investigate some of the factors that may have an impact on the incarcerated inguinal hernias surgical treatment outcome in elderly patients.

Patients and Methods: The study included 149 patients classified in two groups: the study group (> 60 years of age), which included 96 patients, and the control group ( $\leq 60$ years of age), which included 53 patients, treated in the period from January $1^{\text {st }}, 2012$ to December 31st 2016 at the Clinic of General and Abdominal Surgery UCC RS Banja Luka.

Results: Most of the patients had right inguinal hernia $(51.16 \%$ in the study group, $60.37 \%$ in the control group). 82 patients (85.41\%) of the study group suffered from some of the accompanying chronic diseases, opposite to 20 patients (37.73\%) of the control group. Polypropylene mesh was implanted in 105 (70.47\%) patients, while the tension technique was performed in 44 (29.53\%) patients. The duration of incarceration longer than $24 \mathrm{~h}(\mathrm{p}=0.015)$, previous abdominal surgery $(\mathrm{p}=0.001)$, the American Society of Anaesthesiologists physical status classification system (ASA classification) ( $p=0.033)$ and the presence of chronic diseases $(p=0.01)$ appeared to be statistically significant risk factors for performing intestinal resection in the study group, while in the control group, they represented risk factors, but not at the level of statistical significance $(p>0.05)$, except for the duration of incarceration $(p=0.007)$. A higher ASA stage $(p=0.001)$, is the most important risk factor for lethal outcome in both groups of patients.

Conclusion: Incarcerated inguinal hernia is a very serious and demanding surgical problem, particularly in elderly patients. A higher ASA score and the presence of bowel resection are the most important risk factors related to very difficult complications.

Key words: Inguinal hernia, complications, risk factors, comorbidity

(Scr Med 2017:48:17-23)
Božo Krivokuća ${ }^{1}$, Aleksandar Jakovljević ${ }^{2}$ Ostoja Savić, Svetozar Krivokuća ${ }^{4}$, Stefan Stanković ${ }^{5}$

${ }^{1}$ Clinic of General and Abdominal Surgery UCC RS Banja Luka, Faculty of Medicine, the University of Banja Luka,

${ }^{2}$ Faculty of Medicine, the University of Banja Luka,

${ }^{3}$ Clinic of Neurosurgery UCC RS,

Faculty of Medicine, the University of Banja Luka,

${ }^{4}$ Department of Intensive Care Medicine for the conservative branch UCC RS Banja Luka, ${ }^{5}$ Medical Faculty, University of Belgrade.

\section{Contact address:}

Božo Krivokuća

University Clinical Center of

Republic of Srpska

$780 o o$ Banja Luka, Republic of Srpska

Bosnia and Herzegovina e-mail: bozokrivokuca@gmail.com phone number: +387-51-343-322

Submitted: January 30 ${ }^{\text {th }}, 2017$ Accepted: February 6 ${ }^{\text {th }}, 2017$ 


\section{Introduction}

Due to abdominal wall weakness and conditions that increase intra-abdominal pressure, external hernia is more frequently seen in elderly patients. ${ }^{1-4}$ The estimated incidence of the inguinal hernia in patients more than 60 years old is 13 per 1000. ${ }^{5}$ Incarcerated external hernia repairs are one of the most common emergency procedures performed in elderly patients. ${ }^{6}$ Males predominate among the patients up to 75 years of age, while females prevail in the older age. ${ }^{7,8}$ The most recent data indicate that incarcerated inguinal hernia account for about $20 \%$ of all small bowel obstructions. Due to the fact that up to $30 \%$ of bowel incarcerations require intestinal resection, it is also associated with significant morbidity and mortality. ${ }^{.} \mathrm{Up}$ to 75 years of age, $10-15 \%$ of men underwent surgical treatment of inguinal hernia.

\section{Aim of the Study}

The aim of the study is to examine some of the most important factors that may affect the outcome of incarcerated inguinal hernias surgical treatment in elderly patients.

\section{Patients and Methods}

SThe study included 149 patients that underwent surgery in the period from January $1^{\text {st }}, 2012$ to December $31^{\text {st }}$, 2016 at the at the Clinic of General and Abdominal Surgery UCC RS Banja Luka. The patients were divided into two groups: a study group ( $>60$ years of age) and a control group ( $\leq 60$ years of age). During the research, the following parameters were followed: age, gender, type of incarceration (direct/indirect), the ratio of right to left incarcerated inguinal hernia, related chronic diseases, the duration of incarceration (o-24 h, > 24 h), The American Society of Anaesthesiologists (ASA) classification ${ }^{6,16,20}$, type of surgical procedure (tension technique or tension-free technique).
In statistical analysis for comparing values of study and control group, parametrical tests (Student's t-test and ANOVA) were used. Analysis of variables not sorted by the type of normality was made by comparing the nonparametrical tests (Mann-Whitney, U-test, Spearmen Correlation, $\chi 2$ test, Fisher exact probability tests the null hypothesis). Analysis of the influence of some factors was made by inivariant logistic regression and the analysis of survival was made through Cox Regression models, where the invariant "Enter" method was used to determine hazard rate (HR). By means of this method (Enter), the level of risk factors was defined. The statistical analysis was implemented by software package SPSS (version 19) with a statistical probability of $\mathrm{p}<0.05$.

\section{Results}

The study included a total of 149 patients of whom 96 were in the study group and 53 in the control group. The patients in the study group (the average age of 68.23 \pm 7.11 years), were significantly older than those in the control roup whose average age was $51.47 \pm 13.87$ years.

As expected, there was a statistically significant difference in the age of the study group and control group $(p=0,008)$. Out of 96 patients in the study group, 19 had direct and 75 indirect hernia. Out of 56 patients in the control group, 8 had direct and 45 indirect hernia. In both analyzed groups, no statistically significant differences was noticed in the frequency of occurence of the hernia $(x 2: p>0,5)$. The highest number of patients had a right inguinal hernia (84 or $56.38 \%$ of the total number of patients, from which 52 or $61.9 \%$ in the study and 32 or $38.1 \%$ in the control group). 82 patients in the study group (80.39 \%) had some chronic diseases, which was significantly more than in the control group - 20 patients (37.73\%). (Table 1.)

Table 1. Characteristics of the Patients with Incarcerated Inuinal Hernia

\begin{tabular}{|c|c|c|c|c|}
\hline Parameters & Study group n (\%) & Control group n (\%) & Total n (\%) & $p$ \\
\hline Age (years), $x \pm S D$ & $68.23 \pm 7,11$ & $51.47 \pm 13.87$ & & $<0.001$ \\
\hline Men, n (\%) & $86(96)$ & $47(53)$ & $133(100)$ & 0.001 \\
\hline Women, n (\%) & $10(96)$ & $6(53)$ & $16(100)$ & 0.014 \\
\hline Direct hernia, n (\%) & $19(70.37)$ & 8 (29.63) & 27 (100) & \\
\hline Indirect hernia, n (\%) & $75(62.5)$ & $45(37.5)$ & $122(100)$ & \\
\hline Right hernia, n (\%) & $52(61.9)$ & $32(38.1)$ & 84 (100) (56.38) & \\
\hline Left hernia, n (\%) & $30(61.22)$ & $19(38.78)$ & 49 (100) (32.89) & \\
\hline
\end{tabular}


Parameters

Billateral hernia, $\mathrm{n}(\%)$

Chronic diseases, $\mathrm{n}(\%)$

In most cases, the type of surgery in the case of incarcerated inguinal hernia was determined based on the individual assessment of surgeons. Out of 96 patients in the study group, 35 patients were subjected to tension surgical technique (without mesh - the intestinal resection was made), and of 53 patients in the control group, 9 were subjected to tension technique (without

$14(87.5)$

$82(80.39)$
Control group n (\%)

$2(12.5)$

mesh - the intestinal resection was made). Synthetic material (polypropylene mesh) was embedded in 61 patients of the study group and 44 patients of the control group. It can be asserted that much higher percentage of the synthetic material was implemented in the control group in the comparison to the study group with the error level of $\mathrm{p}<0.001$ (Table 2.).

Table 2. Type of Surgical Treatment in the Patients of the study and control group

\begin{tabular}{|c|c|c|c|c|}
\hline $\begin{array}{c}\text { Type of surgical } \\
\text { treaatment }\end{array}$ & $\begin{array}{c}\text { Study group } \\
\text { n (\%) }\end{array}$ & $\begin{array}{c}\text { Control group } \\
n(\%)\end{array}$ & $\begin{array}{l}\text { Total } \\
\text { n (\%) }\end{array}$ & $p$ \\
\hline Tension technique & $35(36.45)$ & $9(16.98)$ & $44(29.53)$ & \\
\hline Synthetic material & $61(63.55)$ & 44 (83.02) & $105(70.47)$ & 0.003 \\
\hline Total & $96(100)$ & $53(100)$ & $149(100)$ & \\
\hline
\end{tabular}

Table 3. Crude Odds Ratio (OR) of the Analyzed Risk Factors for Performing Intestinal Resection

\begin{tabular}{|c|c|c|c|c|}
\hline Parameters & $\begin{array}{l}\text { Study group } \\
\text { OR }(95 \% \mathrm{Cl})\end{array}$ & $p$ & $\begin{array}{l}\text { Control group } \\
\text { OR (95\% Cl) }\end{array}$ & $p$ \\
\hline \multicolumn{5}{|l|}{ Type of incarceration } \\
\hline Direct & 1 & & & \\
\hline Indirect & $6.923(2.37-56.42)$ & 0.079 & 30.859 (9.32 - 53.21) & 0.852 \\
\hline \multicolumn{5}{|c|}{ Duration of incarceration } \\
\hline $0-24$ & 1 & & & \\
\hline$>24$ & 14.39 (2.56 - 96.38) & 0.037 & $27.536(14.82-43.59)$ & 0.089 \\
\hline \multicolumn{5}{|c|}{ Previous abdominal surgery } \\
\hline NO & 1 & & & \\
\hline YES & $3.341(0.121-6.758)$ & 0.005 & $2.319(0.352-3.821)$ & 0.796 \\
\hline \multicolumn{5}{|l|}{ ASA classification } \\
\hline $1-2$ & 1 & & & \\
\hline $3-4$ & $8.764(0.98-64.91)$ & 0.041 & $25.389(10.82-54.35)$ & 0.93 \\
\hline \multicolumn{5}{|l|}{ Chronic diseases } \\
\hline NO & 1 & & & \\
\hline YES & $3.112(1.859-6.457)$ & 0.007 & 7.428 (2.574 - 8.396) & 0.387 \\
\hline
\end{tabular}

CI - confidence interval 
With the usage of inivariant binary logistic regression, in the study group, there were marked statistically significant risk factors for performing intestinal resection: incarceration over $24 \mathrm{~h}(\mathrm{OR}=14.3995 \% \mathrm{CI}$ $=2.56-96.38, \mathrm{p}=0.037)$, previous abdominal surgery $(\mathrm{OR}=3.341 \quad 95 \% \mathrm{CI}=0.121-6.758, \mathrm{p}=0.005), \mathrm{ASA}$ classification $(\mathrm{OR}=8.76495 \% \mathrm{CI}=0.98-64.91, \mathrm{p}=$ $0.041)$ and the presence of chronic diseases (OR $=3.112$ $95 \% \mathrm{CI}=1.859-6.457, \mathrm{p}=0.007$ ). Previously analysed factors in the control group represented the risk factors, but not at the level of statistical significance ( $p>0.05$ ) (Table 3.).

Table 4. shows the summary statistics of Cox regression model and log rank test of patients survival length. The patients' age in the study group did not represent a statistically significant risk factor for lethal outcome (p $=0,657)$. The length of survival in both groups did not seem to differ in age $(\mathrm{p}=0,584)$. In the study group, gender did not represent a statistically significant risk factor for lethal outcome $(p=0,542)$. Also, there was no difference between the groups in terms of the length of survival by gender $(p=0,384)$. By increasing ASA stage for one, a chance for lethal outcome was increased 8,541 times at the level of significance $(p=0,016)$. The presence of intestinal resection was a statistically significant risk factor for lethal outcome, increasing the chance 7,358 times $(\mathrm{p}=0,002)$. The duration of incarceration over $24 \mathrm{~h}$ was a statistically significant risk factor, increasing the chance by 26 times $(\mathrm{p}=0,04)$ and the patients with resection had significantly shorter survival time than the patients without resection $(\mathrm{p}=0,043)$.

Tabela 4. Cox regression model for survival analysis

\begin{tabular}{|c|c|c|c|c|}
\hline Factors & Hazard rate & $95 \% \mathrm{Cl}$ & $p$ & p (Log Rank) \\
\hline \multicolumn{5}{|l|}{ Age (years) } \\
\hline$<60$ & 1 & & & \\
\hline$>60$ & 4.935 & $0.928-23.459$ & 0.657 & 0.584 \\
\hline \multicolumn{5}{|l|}{ Gender } \\
\hline Male & 1 & $0.693-3.514$ & 0.542 & 0.384 \\
\hline Female & 0.471 & & & \\
\hline \multicolumn{5}{|l|}{${ }^{*} \mathrm{ASA}$} \\
\hline Continuous & 8.541 & $2.119-45.874$ & 0.016 & 0.001 \\
\hline \multicolumn{5}{|l|}{ Resections } \\
\hline YES & 1 & & & \\
\hline NO & 7.358 & $3.628-19.987$ & 0.002 & 0.001 \\
\hline \multicolumn{5}{|c|}{ Duration of incarceration } \\
\hline$<24 h$ & 1 & & & \\
\hline$>24 h$ & 26.546 & $0.357-51.437$ & 0.04 & 0.043 \\
\hline $\begin{array}{l}\text { Discussion } \\
\text { Strangulation hern } \\
\text { hernia cannot be re } \\
\text { emphasis on the inc } \\
\text { strangulation incarc } \\
\text { Incarcerated extern } \\
\text { important cause of } \\
\text { people, about } 40 \% \\
\text { treated due to inc } \\
\text { Although some earli }\end{array}$ & $\begin{array}{l}\text { dition in w } \\
\text { abdomen. B } \\
\text { intestinal ob. } \\
\text { a great imp } \\
\text { are the seco } \\
\text { ostruction. }{ }^{9} \mathrm{I} \\
\text { hernias are } \\
\text { intestinal } \\
\text { ve presented }\end{array}$ & \multicolumn{3}{|c|}{$\begin{array}{l}\text { only } 5 \% \text { of all inguinal hernias require urgent surgical } \\
\text { care }^{10} \text {, others have suggested that this percentage is } \\
\text { slightly higher and amounts up to } 13 \% .^{11} \text { Since the } \\
\text { anterior abdominal wall hernia incarceration, followed by } \\
\text { incarceration of intestinal curves, is associated with high } \\
\text { percentage of morbidity and mortality }{ }^{10-12} \text {, urgent surgical } \\
\text { intervention is necessary. There is a generally accepted } \\
\text { view that hernia should be electively managed in order to } \\
\text { avoid later complications. }{ }^{13} \text { However, many patients are } \\
\text { undiagnosed, or consciously reject the proposed surgery, } \\
\text { that resulting in occurrence of many emergency surgeries, }\end{array}$} \\
\hline
\end{tabular}


because of "neglected" cases of hernia. The incarceration percentage increases also by the waiting lists for elective surgery ${ }^{1}$, as well as the fact that non-surgical medical staff did not provide enough information to the patients regarding the danger of incarceration. There were no significant differences in the occurrence frequency of inguinal hernia between the groups, as reported also by other published studies. ${ }^{1,11}$ The published studies have shown that indirect herniasdominate over the direct ones in the proportion ranging from $7: 3: 10: 1 .^{1}$ In our study, out of 96 patients in the study group, 19 patients had direct and 77 had indirect incarcerated inguinal hernia. Of 53 patients in the control group, 8 patients had direct and 45 patients indirect incarcerated inguinal hernia.

Our study has also shown that there was not more frequent occurrence of indirect hernia than direct incarcerated inguinal hernia concerning sex. Another important factor, contributing to the unwanted outcome in the patients with incarcerated inguinal hernia, is related to comorbidity of chronic diseases. ${ }^{17,18}$ The chronic diseases are even more important factor when talking about mortality. ${ }^{19}$

Most of the patients in the study group had some chronic diseases, that is, $82(85.41 \%)$, which was statistically more significant that $20(37.73 \%)$ patients in the control group. Symptoms duration in the study group was accompanied by incarceration duration and lasted from one to three days. Duration increases with the age, which could be observed in other studies, too. ${ }^{1}$ Late hospitalization is generally considered as an important factor for determining the level of intestinal resection and subsequent morbidity and mortality. ${ }^{10,20-22}$ Incarceration and strangulation with or without intestinal obstruction are major complications. ${ }^{23}$ Roughly speaking, about $15 \%$ of all patients with incarcerated intestinal curve require resection due to intestinal necrosis caused by strangulation. ${ }^{20,24}$ Manual reposition may be the method of choice without resection in incarcerated inguinal hernia, although there are no strict criteria to clearly differentiate strangulation, except for the obvious peritonitis. ${ }^{24}$

Higher number of patients studied in both groups who were without intestinal resection and had incarceration that lasted less than $24 \mathrm{~h}(\mathrm{p}=0,002)$ is statistically significant.

Our study showed that, according to Cox's regression model and log-rank test on the patients with and without intestinal resection, the presence of intestinal resection was a statistically significant risk factor for lethal outcome, increasing the chance 7,4 times and the patients with resection had a significantly shorter survival time than those without resection. Open tension-free technique was the most common surgical technique type as in all previous studies, ${ }^{25-27}$ and in both tested groups of our study.

This technique contributed to managing a total of 105 (70.47 \%) patients. Considering a general attitude that synthetic material should not be implanted in patients younger than 30 years of age, because of the netting deformation during a young organism development, as well as because of the surgeons' fear to implant synthetic material in intestinal resection cases due to possible complications, we can argue with the level of error (p $=0,003)$, that much higher number of patients in the control group - $44(83.02 \%)$ had a built-in synthetic material, while the number of patients in the study group was 61 (63.55 \%). In previous studies on patients with incarcerated inguinal hernias, it has been observed that a high ASA score is an independent predicting factor for small bowel gangrene..$^{28}$ Alvarez et al. ${ }^{19}$ not only confirmed the higher rate of complications, but also showed a higher rate of mortality in patients with higher ASA grade. In our study, ASA grade was a risk factor for performing intestinal resection, but not at the level of statistical significance.

\section{Conclusion}

Our study showed that the incarcerated inguinal hernia is a very serious problem. If the inguinal hernia is not operated and managed at the right time, there is a risk that easy surgical problems may lead to various serious complications with a lethal outcome. The risk is higher in elderly patients because of the presence of associated chronic diseases. Statistically significant risk factors for performing intestinal resection in the study group patients were duration of incarceration longer than $24 \mathrm{~h}$, previous abdominal surgery, higher ASA classification, whereas in the control group, the only risk factor was duration of incarceration more than $24 \mathrm{~h}$.

\section{References}

1. Kulah B, Duzgun AP, Moran M, Kulacoglu IH, Ozmen MMM, Coskun F, Emergency hernia repairs in elderly patients. Am J Surg 2001;182(5): 455-9. https://doi.org/10.1016/Sooo2-9610(01)00765-6

2. Gianetta E, de Cian F, Cuneo S, Friedman D, Vitale B, Marinari G, et al. Hernia repair in elderly patients. Br J Surg 1997; 84(7): 983-5. https://doi.org/10.1002/bjs.1800840721 PMid:9240142

3. Nano M. Technique for inguinal hernia repair in the erderly patient. Am J Surg 1983; 146(3): 373-5. https://doi.org/10.1016/0002-9610(83)90419-1 
4. Nehme AE. Groin hernias in elderly patients. Management and prognosis. Am J Surg 1983; 146(2): 257-60. https://doi.org/10.1016/0002-9610(83)90386-o

5. Rosethal RA, Zenilman MME. Surgery in the elderly.In: Townsend CM, Beauchamp RD, Everse MB, Mattox Kl, editors. The biological basis of modern surgical practice. 16th ed. Philadelphia: WB Saunders; 2001.p. 226-46.

6. Primatesta P, Goldacre MJ. Inguinal hernia repair: incidence of elective and emergency surgery, readmission and mortality. Int $\mathrm{J}$ Epidemiol 1996; 25(4): 8359. https://doi.org/10.1093/ije/25.4.835 PMid:8921464

7. Pollak R, Nbylus LM. Strangulating external hernia. In: Nbylus LM, Condon RE, editors. Hernia. 3rd ed. Philadelphia: JB Lippincott; 1989.p. 273-83.

8. Nilson H, Styliandis G, Haapamaki M, Nilsson E, Nordin P. Mortality after groin hernia surgery. Ann Surg 2007; 245(4): 656-60.

https://doi.org/10.1097/01.sla.0000251364.32698.4b PMid:17414617 PMCid:PMC1877035

9. Markogiannakis H. Et al. Acute mechanical bowel obstruction: clinical presentation, etiology, management and outcome. World J Gastroenterol 2007; 13(3): 4327. https://doi.org/10.3748/wjg.v13.i3.432 PMid:17230614 PMCid:PMC4065900

10. Kulah B. et al.Presentation and outcome of incarcerated external hernias in adults. Am J Surg 2001; 181(2): 101-4. https://doi.org/10.1016/Sooo2-9610(oo)00563-8

11. Turaga K, Fitzgibbons RJ Jr, Puri V. Inguinal hernias: should we repair? Surg Clin North Am 2008; 88(1): 12738 , ix.

https://doi.org/10.1016/j.suc.2007.11.004

PMid:18267166

12. Köckerling F1, Alam NN2, Narang SK2, Daniels IR2, Smart NJ2. Biological Meshes for Inguinal Hernia Repair - Review of the Literature. Front Surg.2015 Sep 15;2:48. Review. https://doi.org/10.3389/fsurg.2015.00048

13. Kudryavtsev AV, Kryshen VP. Laparoscopic hernioplasty in incarcerated inguinal hernias. Klin Khir. 2015 May;(5):236. Russian. PMid:26419028

14. Trevisonno M1, Kaneva P1, Watanabe Y1,2, Fried GM1, Feldman LS1, Andalib A1, Vasiliou MC3. Current practics of laparoscopic inguinalhernia repair: a population-based analysis. Hernia. 2015 Oct; 19(5):725-33. https://doi.org/10.1007/s10029-015-1358-5

15. Bessa SS1,2, Abdel-fattah MR3, Al-Sayes IA3, Korayem IT3. Results of prosthetics mesh repair in the emergency management of the acutely incarcerated and/or strangulated groin hernias: a 10-year study. Hernia. 2015 Dec; 19(6):909-14 https://doi.org/10.1007/s10029-015-1360-y

16. Franz MG. Complications of abdominal wall and hernia operations. In: Mullholland MW, Doberty GM, editors. Complications in surgery. Philadelphia: Lippincot Williams - Wilkins; 2006. p. 523-45.

17. Tatar $\mathrm{C}^{1}$, Tüzün IS2, Karsidag $\mathrm{T}_{3}$, Kizilkaya MC4, Yilmaz E5. Prosthetic Mesh Repair for Incarcerated Inguinal Hernia. Balkan Med J.2016 Jul;33(4):434-40. doi: 10.5152/balkanmedj.2016.150137. https://doi.org/10.5152/balkanmedj.2016.150137

18. Bittner JG 4th1. Incarcerated/Strangulated Hernia: Open or Laparoscopic? Adv Surg. 2016 Sep;50(1):67-78. Review. No abstract available. https://doi.org/10.1016/j.yasu.2016.03.006

19. Kjaergaard J, Bay-Nielsen M, Keblet H. Mortality following emergency groin hernia surgery in Denmark. Hernia 2010; 14(4): 351-5.

https://doi.org/10.1007/s10029-010-0657-0 PMid:20396920

20. Akinci $M$, et al. Risk factors related with unfavorable outcomes in groin hernia repairs. Hernia 2010; 14(5): 489-93.

https://doi.org/10.1007/s10029-010-0683-y PMid:20524024

21. Atila K, et al. Prosthetic repair of acutely incarcerated groin hernias: a prospective clinical observational cohort study. Langenbecks Arch Surg 2010; 395(5): 5638. https://doi.org/10.1007/s00423-008-0414-3 PMid:18758807

22. Fuglestad $\mathrm{MA}^{1,2}$, Waisbren $\mathrm{SJ}_{3}, 4$. Two-port totally extraperitoneal inguinal hernia repair: a 10-year experience. Hernia.2016 Jun;20(3):423-8.

https://doi.org/10.1007/s10029-015-1402-5

23. Amid PK, Lichtenstein tension-free hernioplasty: its inception, evolution, and principles. Hernia 2004; 8(1): $1-7$.

https://doi.org/10.1007/s10029-003-0160-y PMid:14505236

24. Yang $\mathrm{S}^{1}$, Zhang G, Jin C, Cao J, Zhu Y, Shen Y, Wang M. Transabdominalprepiritoneal laparoscopic approach for incarcerated inguinalhernia repair: A report of 73 cases. Medicine (Baltimore). 2016 Dec; 95(52):e5686. https://doi.org/10.1097/md.0000000000005686

25. EU Hernia Trialists Collaboration. Repair of groin hernia with synthetic mesh: meta-analysis of randomized controlled trials. Ann Surg2002; 235(3): 322-32. https://doi.org/10.1097/00000658-200203000-00003

26. Derici H, Unalp HR, Bozdag AD, Nazli O, Tansug T, Kamer E. Factors affecting morbidity and mortality in incarcerated abdominal wallhernias. Hernia 2007; 11(4): 341-6. https://doi.org/10.1007/s10029-007-0226-3 PMid:17440794

27. Dapri $\mathrm{G}^{1,2}$, Gerard $\mathrm{L}^{3}$, Paesmans $\mathrm{M}^{4}$, Cadiere $\mathrm{GB}^{3}$, Saussez $\mathrm{S}^{5}$. First 200 consecutive transumbilical single-incision laparoscopic TEPs. Hernia. 2016Dec 23.doi: 10.1007/s 10029-016-1564-9. 
28. Tanoue $\mathrm{K}^{1}$, Okino $\mathrm{H}^{2}$, Kanazawa $\mathrm{M}^{2}$, Ueno $\mathrm{K}^{2}$. Singleincision laparoscopic transabdominalpreperitoneal mesh hernioplasty: results in 182 Japanese patients. Hernia. 2016 Dec; 20(6): 797-803. https://doi.org/10.1007/s10029-016-1540-4 PMid:27785630
29. Sasaki $A^{1}$, Tekeuchi $Y^{2}$, Izumi $\mathrm{K}^{2}$, Morimoto $\mathrm{A}^{2}$, Inomata $\mathrm{M}^{3}$, Kitano $\mathrm{S}^{3}$. Two-stage laparoscopic treatment for strangulated inguinal, femoral and obturatorhernias: totally extraperitoneal repair followed by intestinal resection assisted by intraperitoneal laparoscopic exploration. Hernia. 2016 Jun;20(3):483-8. https://doi.org/10.1007/s10029-014-1272-2 Dav

\section{Komplikacije hirurškog liječenja uklještenih preponskih kila}

\section{SAŽETAK}

Uvod: Uklještenje je stanje kile opasno po život i predstavlja najčešću komplikaciju, posebno kod starijih osoba. Karakteriše je kompromitacija vaskularizacije sadržaja kilne kese. Hirurško liječenje uklještenih preponskih kila predstavlja jednu od najčešćih hirurških intervencija kod starijih osoba i procentualno raste sa godinama starosti.

Cilj rada: Cilj ove studije je ispitivanje faktora koji mogu uticati na ishod hirurškog liječenja uklještenih preponskih kila u odnosu na starosnu dob bolesnika.

Ispitanici i metode: Studija je obuhvatila 149 bolesnika, razvrstanih u 2 grupe: ispitivana (više od 60 godina), u kojoj je bilo 96 bolesnika i kontrolna grupa (manje od 60 godina), u kojoj je bilo 53 bolesnika, liječenih u periodu od 01.01.2012. do 31.12.2016. u Klinici za opštu i abdominalnu hirurgiju UKC RS Banja Luka.

Rezultati: Češće je bila zastupljena desna preponska kila (54,16\% u ispitivanoj, 60,37\% u kontrolnoj grupi). 82 bolesnika $(85,41 \%)$ u ispitivanoj grupi su imala neko od pratećih hroničnih oboljenja, nasuprot 20 bolesnika (37,73\%) u kontrolnoj grupi. Polipropilenska mrežica bila je ugrađena kod 105 (70,47\%) bolesnika, a tenzionom tehnikom je zbrinuto 44 (29,53\%) bolesnika. Dužina uklještenja preko 24h ( $p=0,015)$, prethodne abdominalne operacije ( $p=0,001)$, klasifikacioni sistem fizičkog stanja (ASA klasifikacija) $(p=0,033)$ i prisustvo hroničnih oboljenja $p=0,01)$ izdvojili su se kao statistički značajni faktori rizika od izvođenja resekcije crijeva $u$ ispitivanoj grupi, dok su u kontrolnoj grupi predstavljali faktore rizika bez statističke značajnosti (p veće od 0.05), izuzev dužine uklještenja ( $p=0.007)$. Viši ASA stadijum ( $p=0.001$ ) bio je najznačajniji faktor rizika od letalnog ishoda bolesnika u obe ispitivane grupe.

Conclusion: Uklještena preponska kila veoma je ozbiljan i zahtjevan hirurški problem, posebno kod starijih osoba. Viši ASA skor i resekcija crijeva predstavljali su najvažnije faktore rizika za teške komplikacije.

Ključne riječi: Preponske kile, komplikacije, faktori rizika, komorbiditet 